\title{
A Frankston Phase Settlement and Cemetery at the H. C. Slider Site on the Neches River in Cherokee County, Texas
}

Timothy K. Perttula

Heritage Research Center, Stephen F. Austin State University

Bo Nelson

Heritage Research Center, Stephen F. Austin State University

Follow this and additional works at: https://scholarworks.sfasu.edu/ita

Part of the American Material Culture Commons, Archaeological Anthropology Commons, Environmental Studies Commons, Other American Studies Commons, Other Arts and Humanities Commons, Other History of Art, Architecture, and Archaeology Commons, and the United States History Commons

Tell us how this article helped you.

This Article is brought to you for free and open access by the Center for Regional Heritage Research at SFA ScholarWorks. It has been accepted for inclusion in Index of Texas Archaeology: Open Access Gray Literature from the Lone Star State by an authorized editor of SFA ScholarWorks. For more information, please contact cdsscholarworks@sfasu.edu. 


\section{A Frankston Phase Settlement and Cemetery at the H. C. Slider Site on the Neches River in Cherokee County, Texas}

\section{Creative Commons License}

\section{(c) (1) \&}

This work is licensed under a Creative Commons Attribution-NonCommercial 4.0 International License 


\title{
A Frankston Phase Settlement and Cemetery at the H. C. Slider Site on the Neches River in Cherokee County, Texas
}

\author{
Timothy K. Perttula and Bo Nelson
}

\section{INTRODUCTION}

The H. C. Slider site is a previously undocumented Late Caddo habitation site and cemetery in the Neches River valley in western Cherokee County, in the East Texas Pineywoods (Figure 1). The site was found and investigated by Buddy Calvin Jones in November and December 1967. His notes and collections from the site are curated at the Gregg County Historical Museum in Longview, Texas.

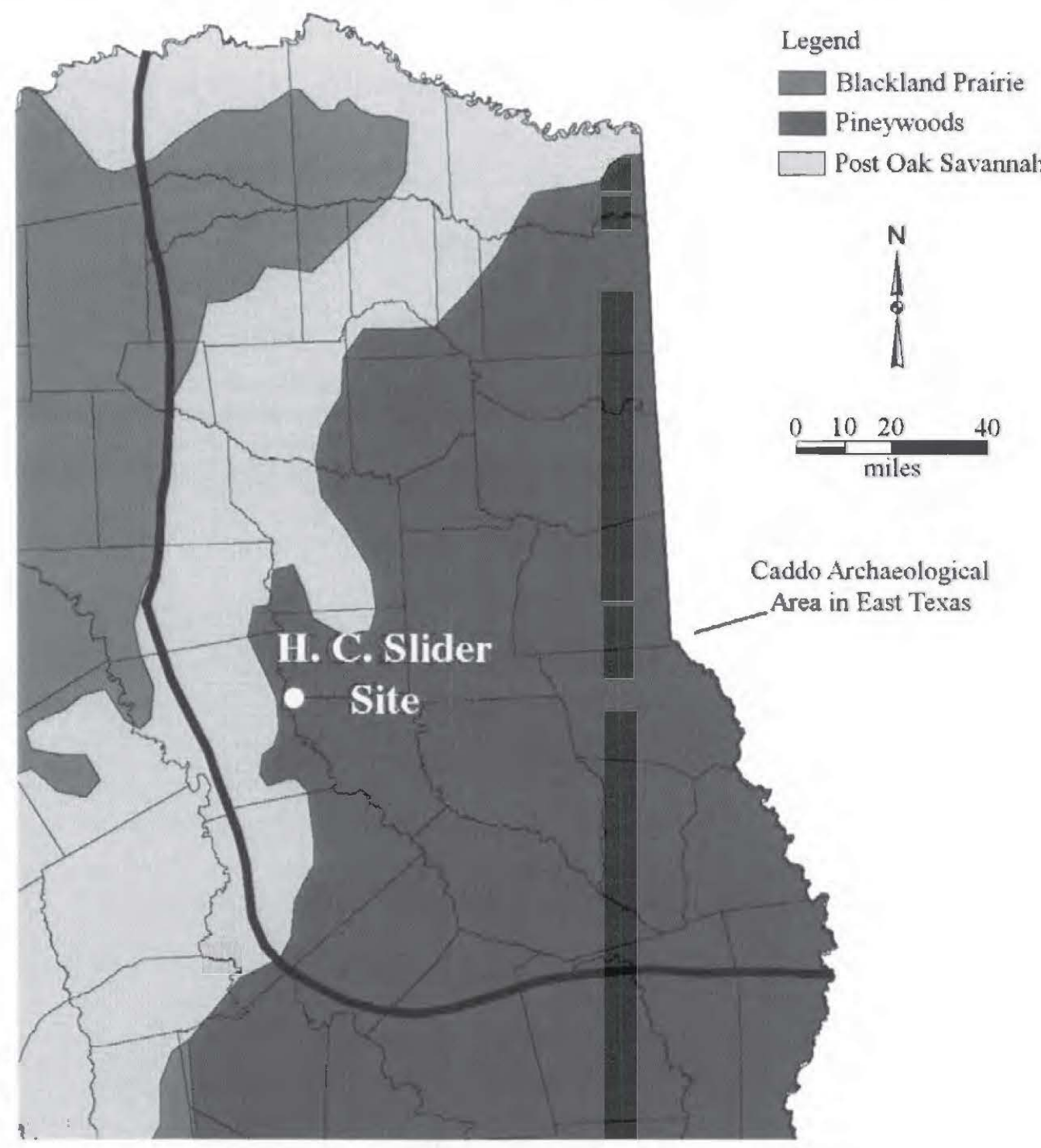

Figure 1. The location of the H. C. Slider site in East Texas. 
According to Jones' notes, the site is on three sandy knolls along a Neches River terrace, approximately 11 miles southwest of the city of Jacksonville. These knolls (A-C) have midden deposits with ceramic sherds and lithic artifacts (Figure 2). Knoll A has a cemetery, and Jones excavated four burials (Burials 1-4) at the northern end of the knoll (Figure 3).

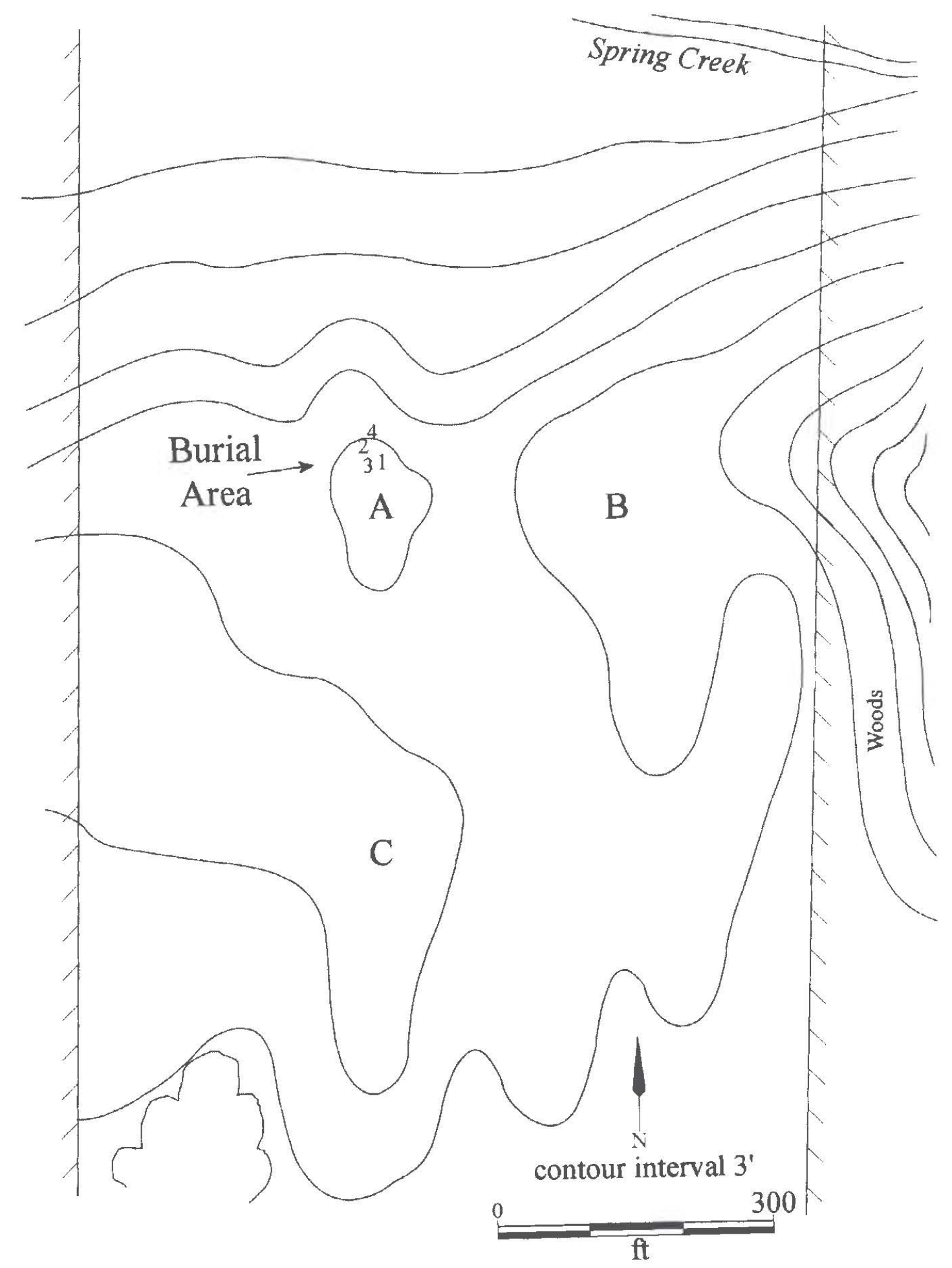

Figure 2. Map of Knolls A-C at the H. C. Slider site. 

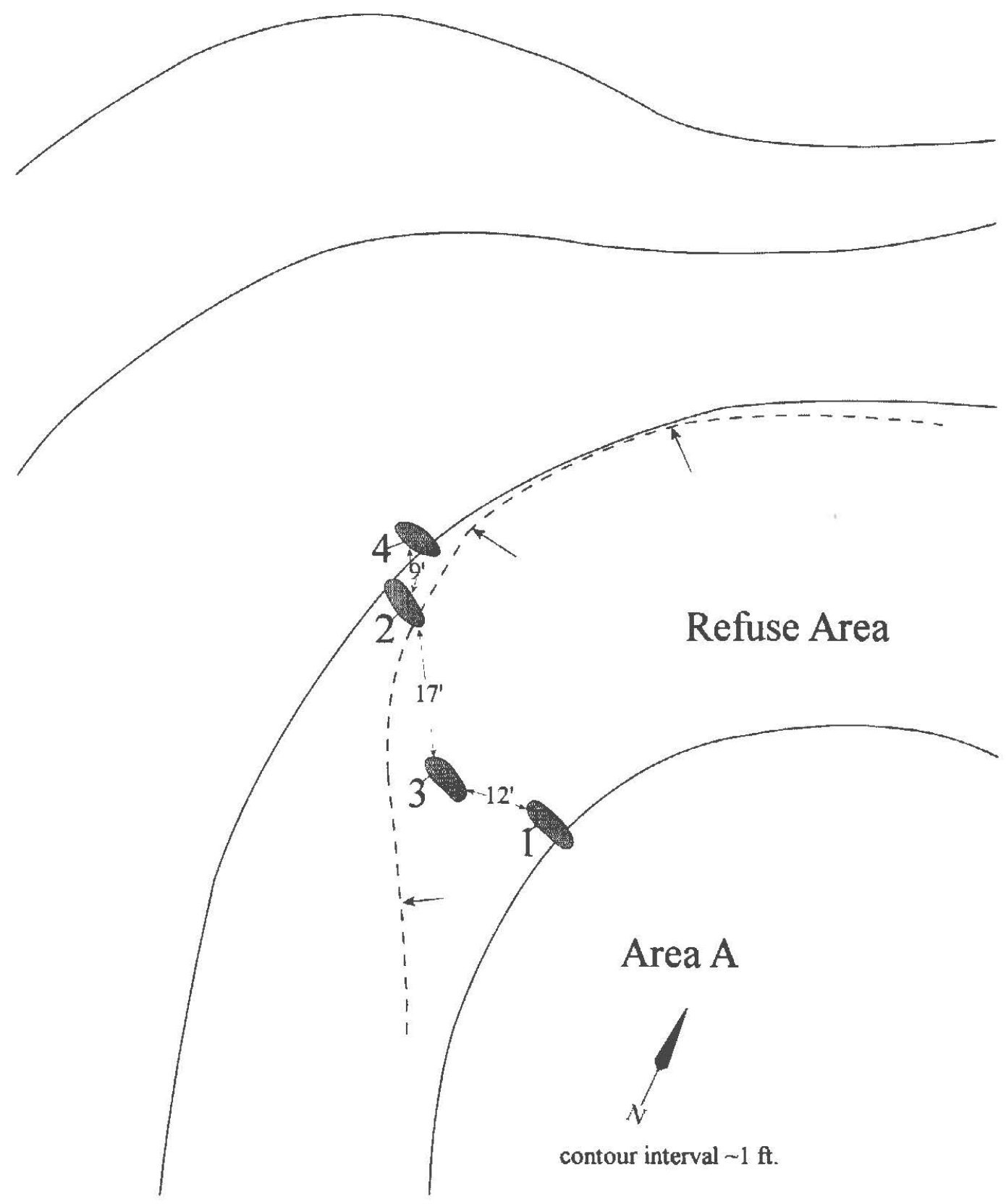

Figure 3. Burials 1-4 in Area A at the H. C. Slider site.

\section{BURIAL EXCAVATIONS}

The four burials excavated by Jones at the H. C. Slider site are dispersed across a ca. $10 \mathrm{~m}$ long area at the northwestern edge of the Area A knoll (see Figure 4). The burial pits were oriented northwest-southeast, with single individuals interred in an extended position, with their heads apparently at the southeastern end of the pits, facing to the northwest. Each of the burials contains ceramic vessels as associated funerary offerings. 


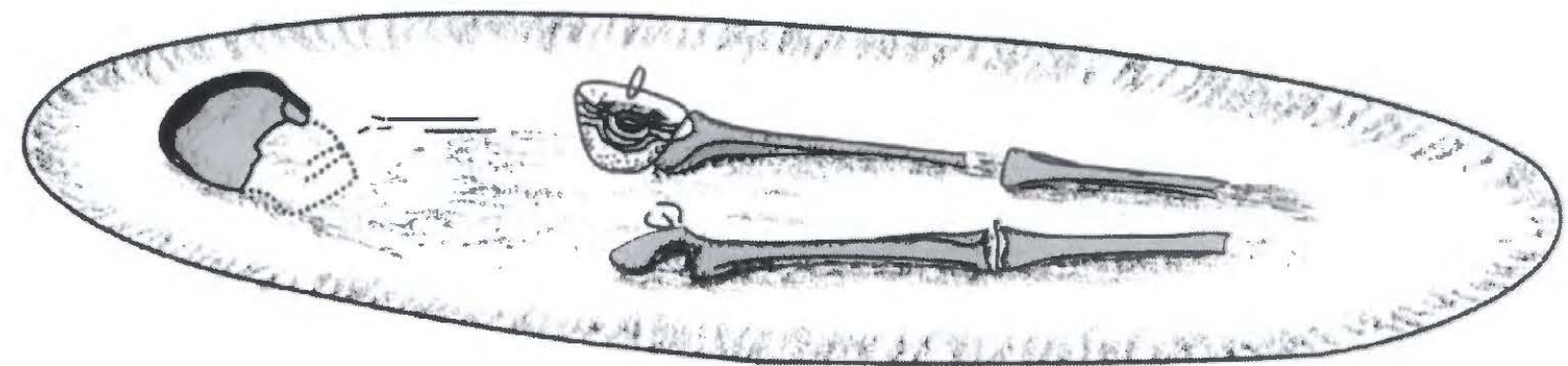

Figure 4. Burial 1 at the H. C. Slider site.

\section{Burial 1}

Burial 1 is that of a young adult; the human remains were poorly preserved, including part of the cranium and portions of the upper and lower leg bones (Figure 4). The burial pit extended to $1.12 \mathrm{~m}$ below the surface, reaching about $2 \mathrm{~cm}$ into the sterile B-horizon red clay. A single engraved effigy vessel was placed with this individual (Figure 5), resting against the left leg and pelvis area.

\section{SITE NAME OR SITE NUMBER: H. C. Slider}

VESSEL NO.: 2003.08.67, Burial 1, Vessel 1

NON-PLASTICS AND PASTE: grog

VESSEL FORM: Bowl with a tab tail $(37 \times 24 \mathrm{~mm})$ and an effigy head $(51 \times 10 \mathrm{~mm})$, probably a turkey (Figure 6a)

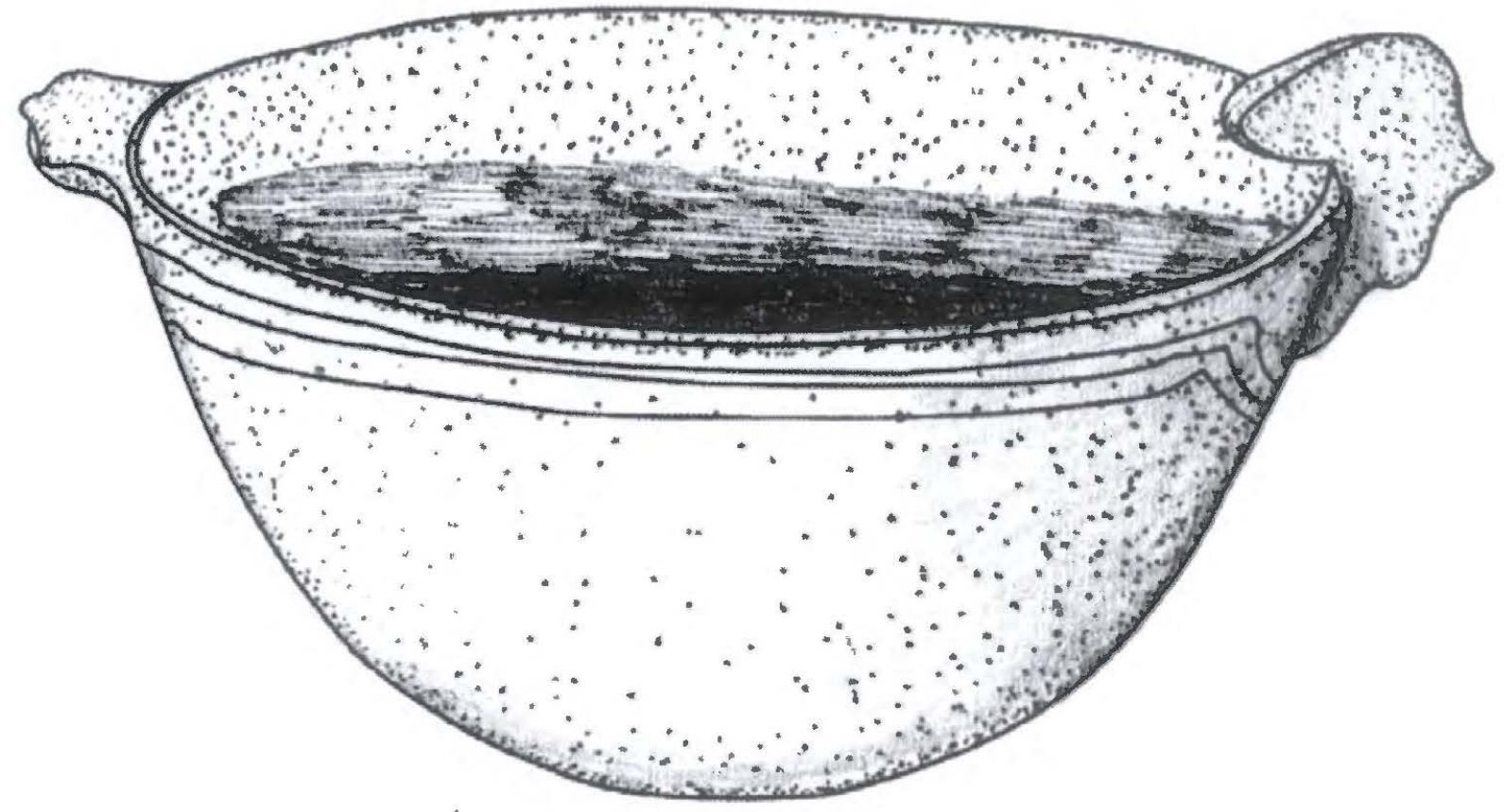

Figure 5. Vessel 1, Burial 1 at the H. C. Slider site. 


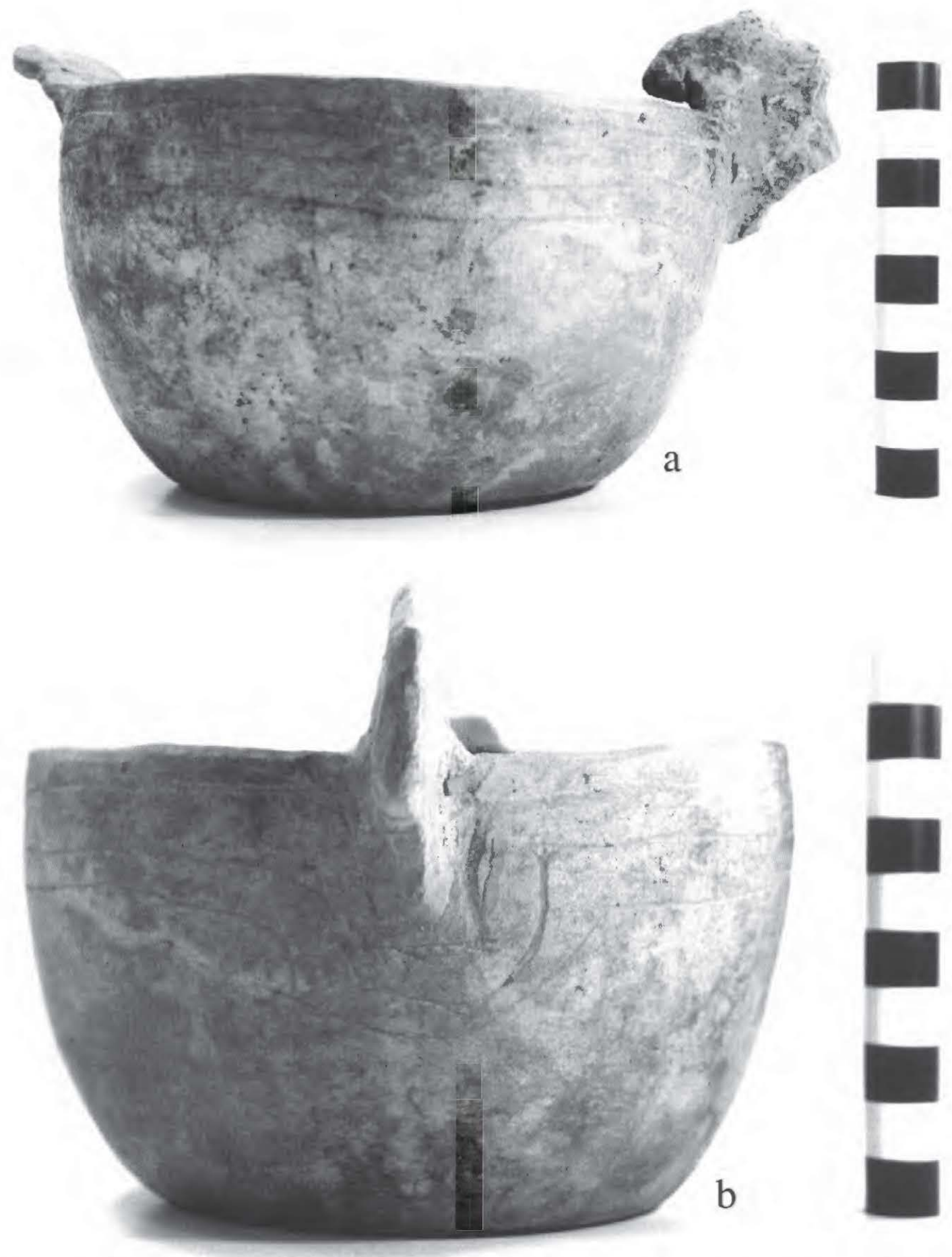

Figure 6. Hood Engraved, var. Hood effigy bowl in Burial 1: a, side view; b, view under effigy head.

RIM AND LIP FORM: Direct rim with a rounded lip CORE COLOR: $\mathrm{F}$ (fired in a reducing environment and cooled in the open air) INTERIOR SURFACE COLOR: yellowish-brown; fire clouds on the rim and body 
EXTERIOR SURFACE COLOR: dark yellowish-brown; fire clouds on the rim, body, and base

WALL THICKNESS (RIM, BODY, AND BASE IN MM): rim, $8.2 \mathrm{~mm}$

INTERIOR SURFACE TREATMENT: smoothed

EXTERIOR SURFACE TREATMENT: burnished

HEIGHT (IN CM): $8.4 ; 10.5 \mathrm{~cm}$ at the top of the effigy head

ORIFICE DIAMETER (IN CM): 14.0

DIAMETER AT BOTTOM OF RIM OR NECK (IN CM): N/A

BASE DIAMETER (IN CM) AND SHAPE OF BASE: 9.5; flat and circular

ESTIMATED VOLUME (IN LITERS): 0.47

DECORATION (INCLUDING MOTIF AND ELEMENTS WHEN APPARENT): There are three horizontal engraved lines encircling the vessel along the rim (Figure 6a). Underneath the effigy head and the tab tail, the horizontal engraved lines turn to curvilinear lines as they dip under the vessel appendages (Figure $6 \mathrm{~b}$ ).

PIGMENT USE AND LOCATION ON VESSEL: red pigment rubbed in the engraved lines

TYPE AND VARIETY [IF KNOWN]: Hood Engraved, var. Hood (Perttula 2011:271)

\section{Burial 2}

Burial 2 was in a grave pit that was $91 \mathrm{~cm}$ in depth and $76 \mathrm{~cm}$ in width; the burial pit was estimated to be $1.52 \mathrm{~m}$ in length (Figure 7). Only fragmentary cranial remains and teeth were preserved in the grave. Six ceramic vessels were placed in the grave as funerary offerings: two jars above the head, a bottle by what would have been the left leg, and three vessels (two carinated bowls and a jar) by what would have been the lower right leg (see Figure 7). The vessels include two Killough Pinched jars, one with a pedestal base (Figure 8a, d), a Poynor Engraved bottle (Figure 8b), a Poynor Engraved carinated bowl (Figure 8c), a plain globular carinated bowl (Figure 8f), and a Bullard Brushed jar (Figure 8e).

Three of the vessels from Burial 2 remain in the Gregg County Historical Museum collections, and they have been documented for this article.

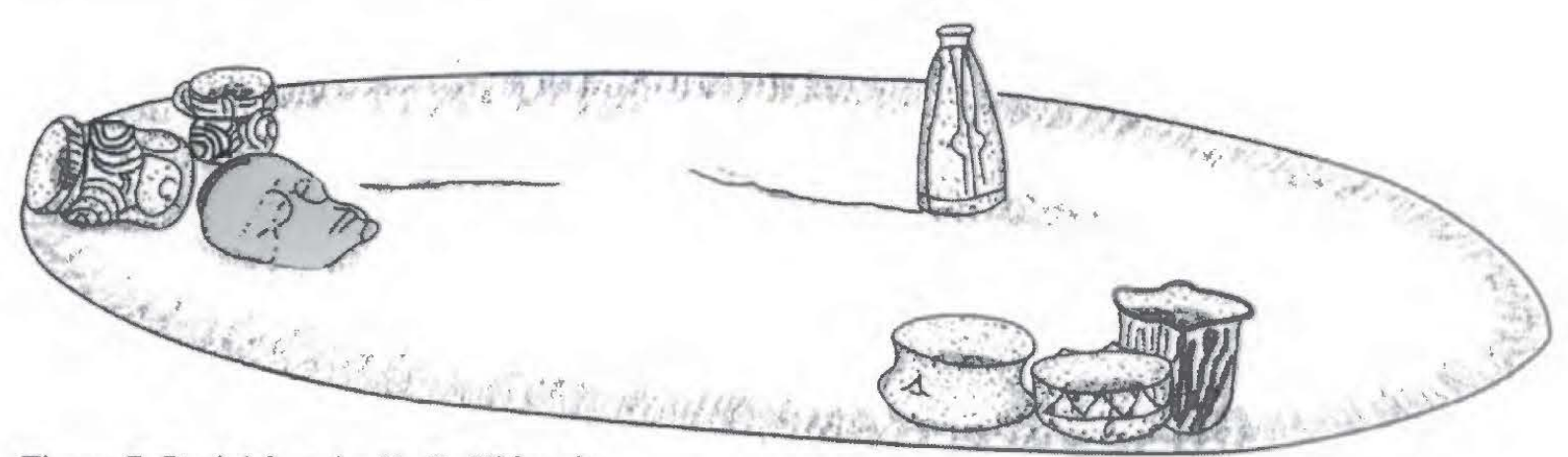

Figure 7. Burial 2 at the H. C. Slider site. 

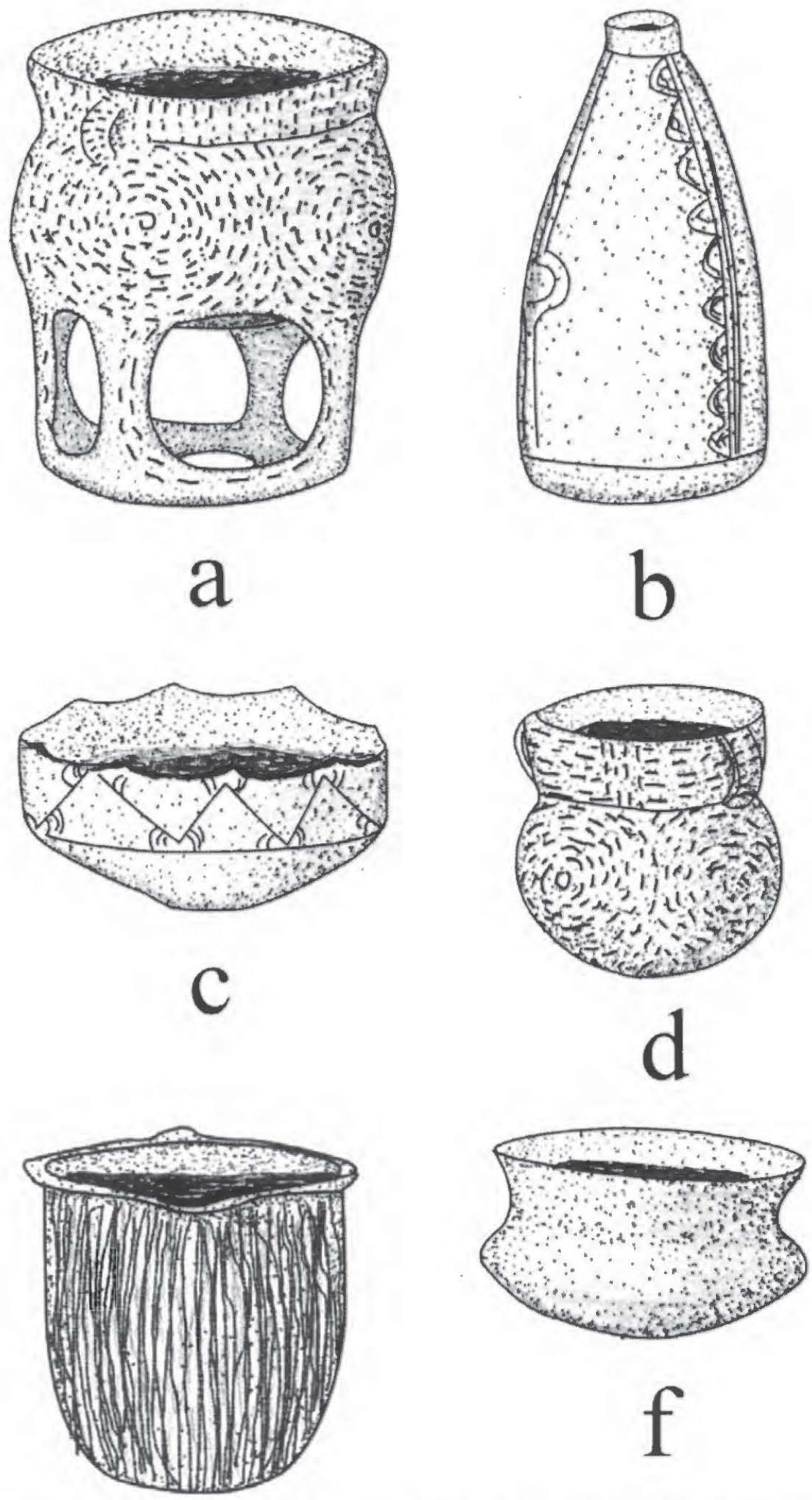

Figure 8. Drawings of Vessels 2-7 from Burial 2 at the H. C. Slider site: a, Killough Pinched (Vessel 2); b, Poynor Engraved bottle (Vessel 4); c, Poynor Engraved carinated bowl (Vessel 6); d, Killough Pinched jar (Vessel 3); e, Bullard Brushed jar (Vessel 7); f, plain carinated bowl (Vessel 5). 
SITE NAME OR SITE NUMBER: H. C. Slider

VESSEL NO.: 2003.08.24, Burial 2, Vessel 3 (see Figure 8d)

NON-PLASTICS AND PASTE: grog

VESSEL FORM: Jar with two strap handles (Figure 9); the strap handles measure $43 \times 23 \mathrm{~mm}$ in height and width

RIM AND LIP FORM: Everted rim and a rounded, exterior folded lip

CORE COLOR: B (fired and cooled in a reducing environment)

INTERIOR SURFACE COLOR: very dark grayish-brown

FXTERIOR SURFACE COLOR: dark grayish-brown

WALL THICKNESS (RIM, BODY, AND BASF IN MM): rim, $5.5 \mathrm{~mm}$

INTERIOR SURFACE TREATMENT: smoothed

EXTERIOR SURFACE TREATMENT: none

HEIGHT (IN CM): 11.5

ORIFICE DIAMETER (IN CM): 10.8

DIAMETER AT BOTTOM OF RIM OR NECK (IN CM): 10.4

BASE DIAMETER (IN CM) AND SHAPE OF BASE: 7.7; flat and circular

ESTIMATED VOLUME (IN LITERS): 1.2

DECORATION (INCLUDING MOTIF AND EI.EMENTS WHEN APPARENT): There are six horizontal rows of pinching on the rim, divided by either strap handles (with horizontal pinched decorations on them) or two sets of four vertical pinched rows (Figure 9). The vessel body has four pinched concentric circles divided by upper and lower incised chevron-shaped elements (Figure 9).

PIGMENT USE AND LOCATION ON VESSFI: none

TYPE AND VARIETY [IF KNOWN]: Killough Pinched

SITE NAME OR SITE NUMBER: H. C. Slider

VESSEL NO:: 2003.08.86, Burial 2, Vessel 6 (see Figure 8c)

NON-PLASTICS AND PASTE: grog, bone, and hematite

VESSEI. FORM: Carinated bowl with six lip lugs (Figure 10)

RIM AND LIP FORM: Direct rim and a rounded lip 


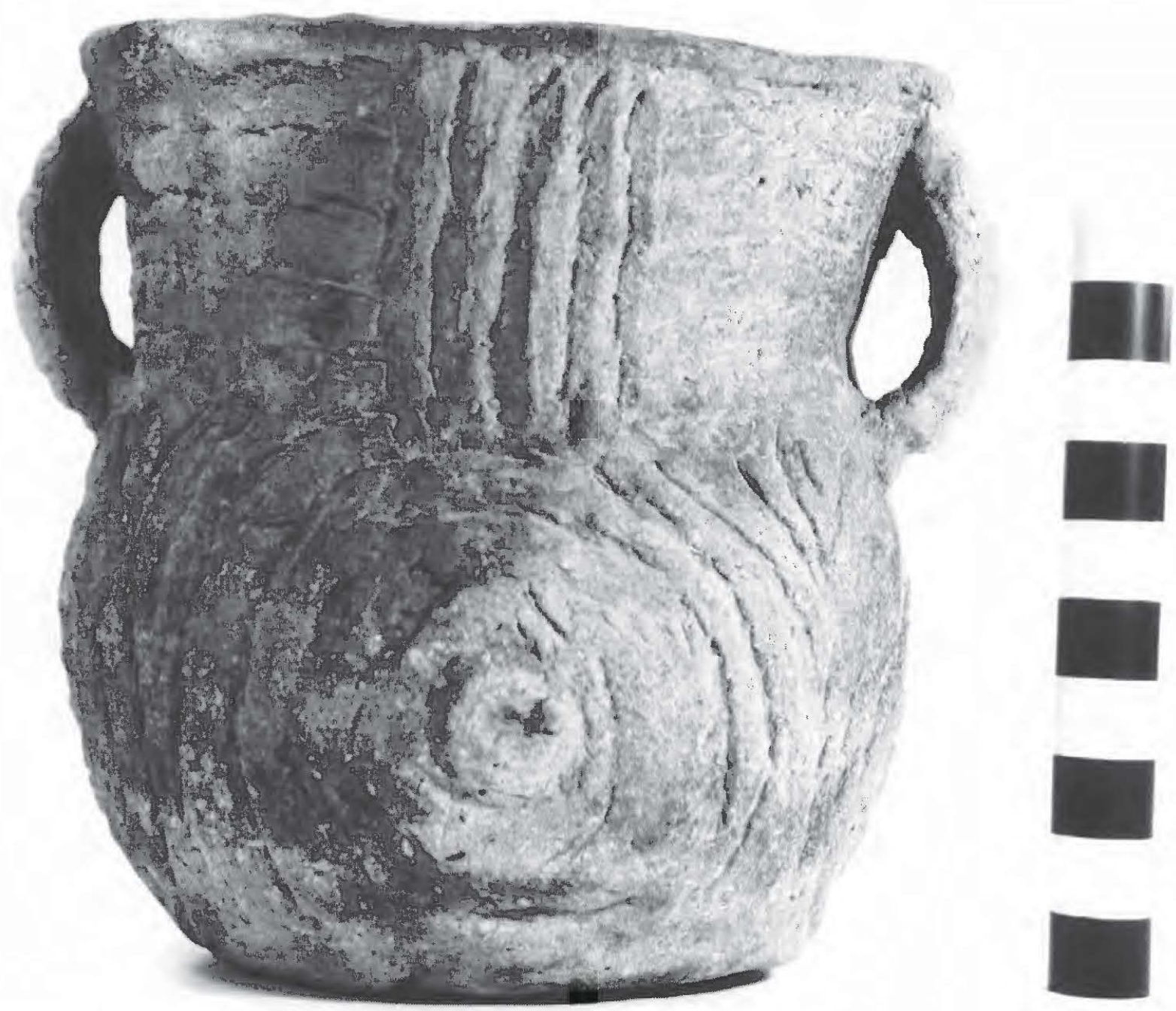

Figure 9. Killough Pinched jar, Burial 2, Vessel 3.

CORE COLOR: A (fired and cooled in an oxidizing environment)

INTERIOR SURFACE COLOR: reddish-brown; fire clouds on the body

EXTERIOR SURFACE COLOR: reddish-brown to yellowish-brown; fire clouds on the body and base

WALL THICKNESS (RIM, BODY, AND BASE IN MM): rim, 5.9 mm

INTERIOR SURFACE TREATMENT: smoothed

EXTERIOR SURFACE TREATMENT: burnished

HEIGHT (IN CM): 9.4

ORIFICE DIAMETER (IN CM): 15.5 

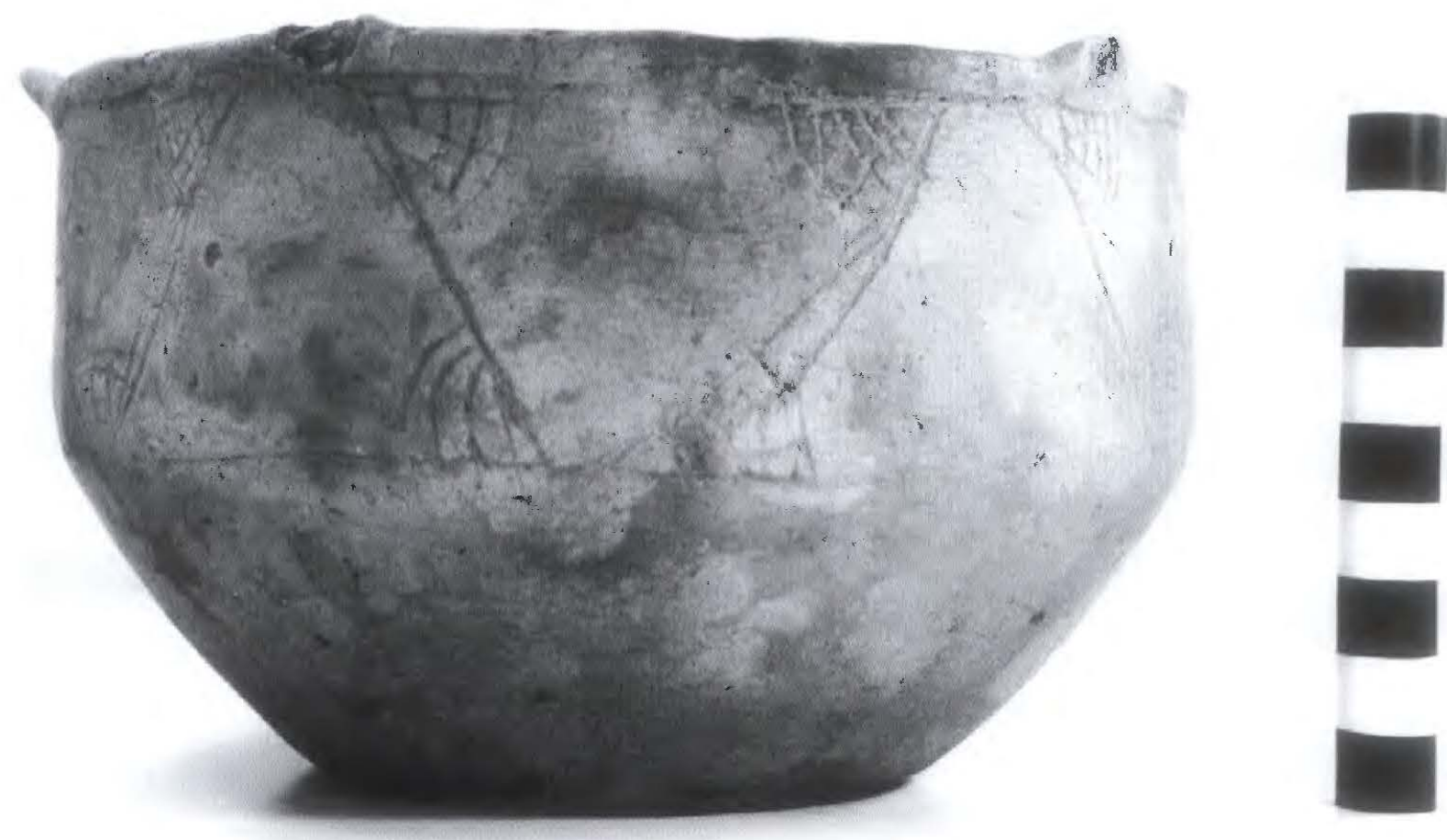

Figure 10. Poynor Engraved, Var. A carinated bowl, Burial 2, Vessel 6.

DIAMETER AT BOTTOM OF RIM OR NECK (IN CM): 15.5

BASE DIAMETER (IN CM) AND SHAPE OF BASE: 8.3; flat and circular

ESTIMATED VOLUME (IN LITERS): 0.88

DECORATION (INCLUDING MOTIF AND ELEMENTS WHEN APPARENT): The rim panel has seven sets of engraved nested triangles around the vessel (see Figure 10). Each of the nested triangles has either sets of curvilinear lines, hatched areas, or cross-hatched ovals in two or three corners.

PIGMENT USE AND LOCATION ON VESSEL: none

TYPE AND VARIETY [IF KNOWN]: Poynor Engraved, Var. A (Perttula 2011:Figure 6-65)

SITE NAME OR SITE NUMBER: H. C. Slider

VESSEL NO.: 2003.08.759, Burial 2, Vessel 7 (see Figure 8e)

NON-PLASTICS AND PASTE: bone, grog, and hematite

VESSEL FORM: Jar with a short rim and four flattened outward rim peaks (Figure 11)

RIM AND LIP FORM: Direct rim and rounded, exterior folded lip

CORE COLOR: $\mathrm{G}$ (fired in a reducing environment and cooled in the open air) 
INTERIOR SURFACE COLOR: very dark grayish-brown to black; organic residue on the rim and body

EXTERIOR SURFACE COLOR: yellowish-brown; fire clouds and organic residue on the body

WALL THICKNESS (RIM, BODY, AND BASE IN MM): rim, $7.0 \mathrm{~mm}$

INTERIOR SURFACE TREATMENT: smoothed

EXTERIOR SURFACE TREATMENT: none

HEIGHT (IN CM): 16.7

ORIFICE DIAMETER (IN CM): 14.1

DIAMETER AT BOTTOM OF RIM OR NECK (IN CM): 13.8

BASE DIAMETER (IN CM) AND SHAPE OF BASE: 8.9; flat and circular

ESTIMATED VOLUME (IN LITERS): 2.1

DECORATION (INCLUDING MOTIF AND ELEMENTS WHEN APPARENT): There is vertical brushing on the rim and the body, extending to within $5 \mathrm{~cm}$ of the vessel base (Figure 11).

PIGMENT USE AND LOCATION ON VESSEL: none

TYPE AND VARIETY [IF KNOWN]: Bullard Brushed

\section{Burial 3}

Burial 3 is that of a poorly preserved adult interment in a pit that was $1.75 \mathrm{~m}$ in length, $76 \mathrm{~cm}$ in width, and $96 \mathrm{~cm}$ in depth (Figure 12). Only leg bones were preserved, along with a few fragments of crania and tecth. There were frequent charcoal lumps along the floor of the grave, suggesting that fires had been lit in the grave before the body was interred, probably part of the Six Day burial rites of the Caddo (cf. Gonzalez 2005).

Three vessels (Vessels 8-10) are associated with Burial 3 (see Figure 12), two by the head and upper left leg and a third that was found at $46 \mathrm{~cm}$ bs in the grave lill. These vessels are a brushed-pinched jar with strap handles (Figure 13c), a large plain carinated bowl (Figure 13f), and a diagonal incised jar (Figure 13d).

One of the vessels from Burial 3 remains in the H.C. Slider collections at the Gregg County Historical Museum, a cf. Killough Pinched jar with two strap handles (see Figure 13c).

\section{SITE NAME OR SITE NUMBER: H. C. Slider}

VESSEL NO.: 2003.08.58, Burial 3, Vessel 9

NON-PLASTICS AND PASTE: grog and bone

VESSEL FORM: Jar with two strap handles (58 x $36 \mathrm{~mm}$ in height and width) (Figure 14)

RIM AND LIP FORM: Everted rim and rounded lip 

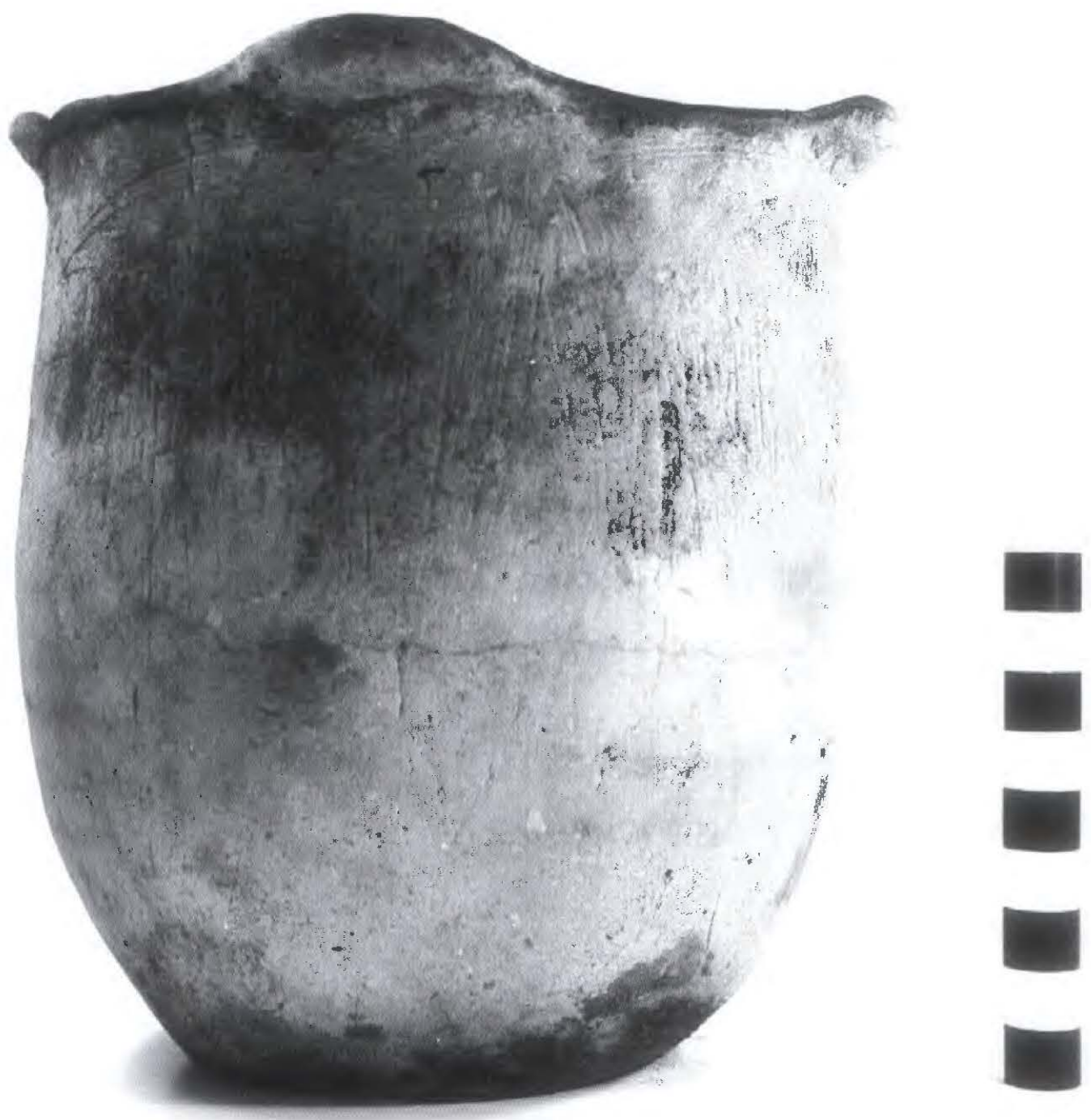

Figure 11. Bullard Brushed jar, Burial 2, Vessel 7.
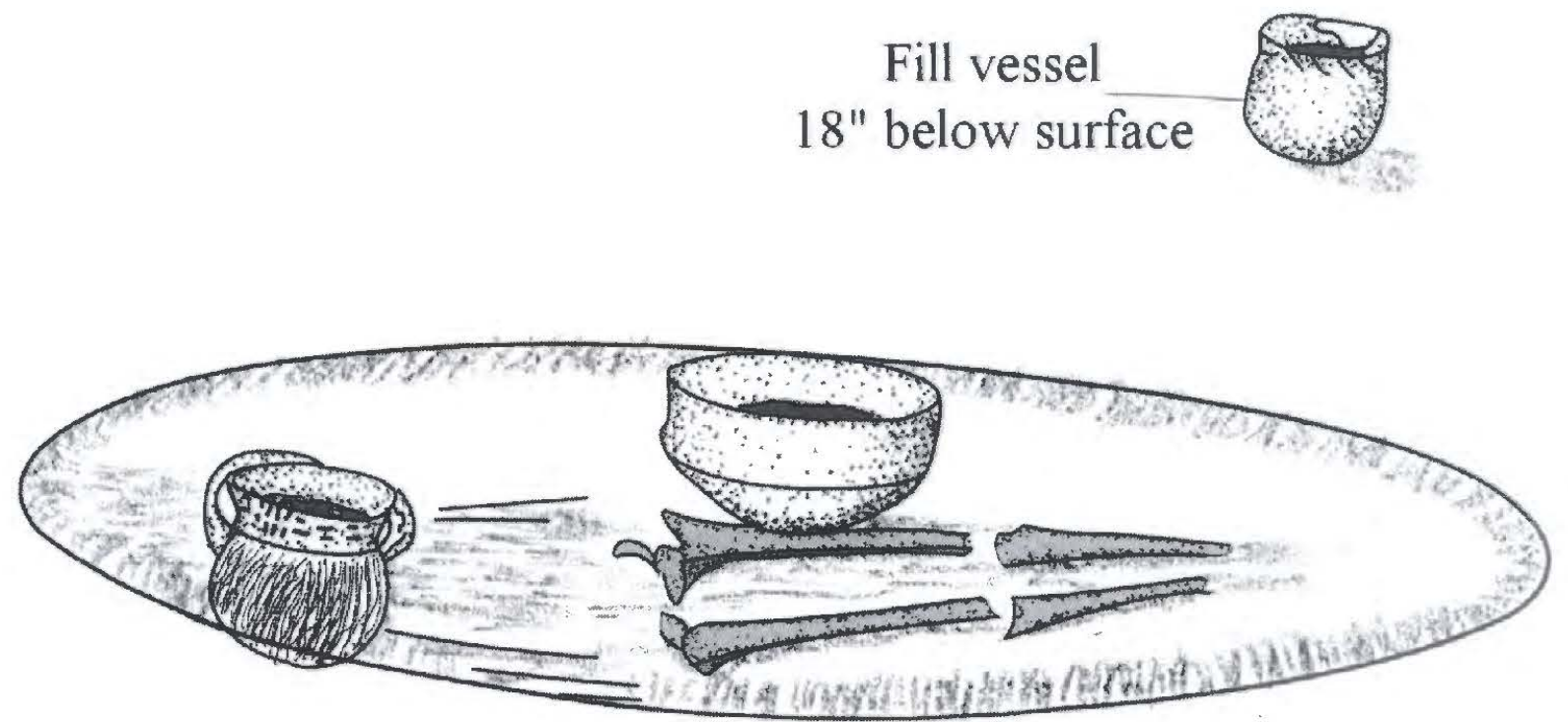

Figure 12. Burial 3 at the H. C. Slider site. 

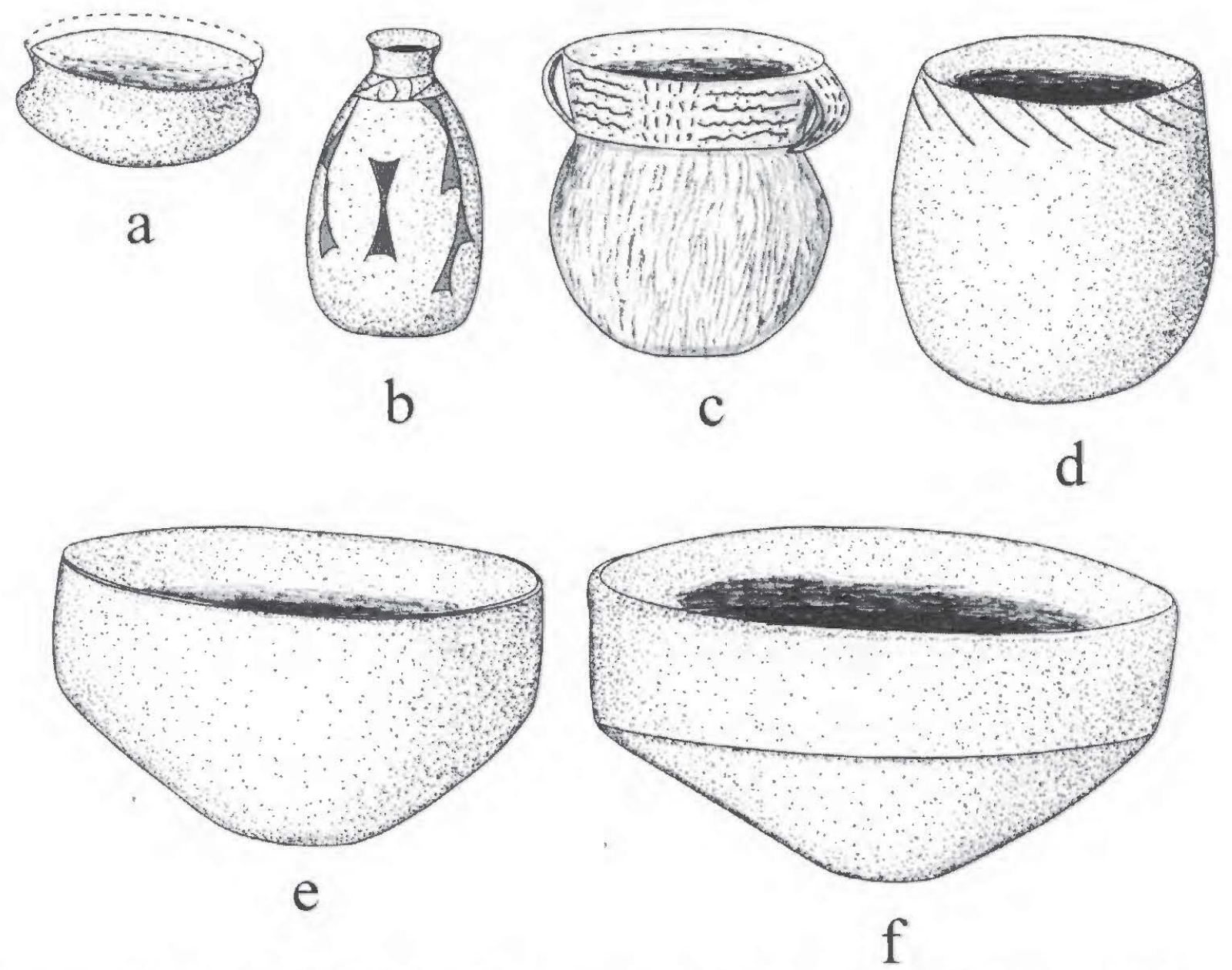

Figure 13. Vessels from Burial 3 and 4 at the H. C. Slider site: a, plain carinated bowl (Vessel 12, Burial 4); b, Poynor Engraved bottle (Vessel 11, Burial 4); c, pinched-brushed jar (Vessel 9, Burial 3); d, incised jar (Vessel 8, Burial 3); e, plain carinated bowl (Vessel 13, Burial 4); f, plain carinated bowl (Vessel 10, Burial 3).

CORE COLOR: $\mathrm{F}$ (fired in a reducing environment but cooled in the open air)

INTERIOR SURFACE COLOR: yellowish-brown; fire clouds and organic residue on the rim and body

EXTERIOR SURFACE COLOR: yellowish-brown; fire clouds on the rim, body, and base

WALL THICKNESS (RIM, BODY, AND BASE IN MM): rim, $7.1 \mathrm{~mm}$

INTERIOR SURFACE TREATMENT: smoothed

EXTERIOR SURFACE TREATMENT: none

HEIGHT (IN CM): 16.9

ORIFICE DIAMETER (IN CM): 15.0

DIAMETER AT BOTTOM OF RIM OR NECK (IN CM): 14.6 


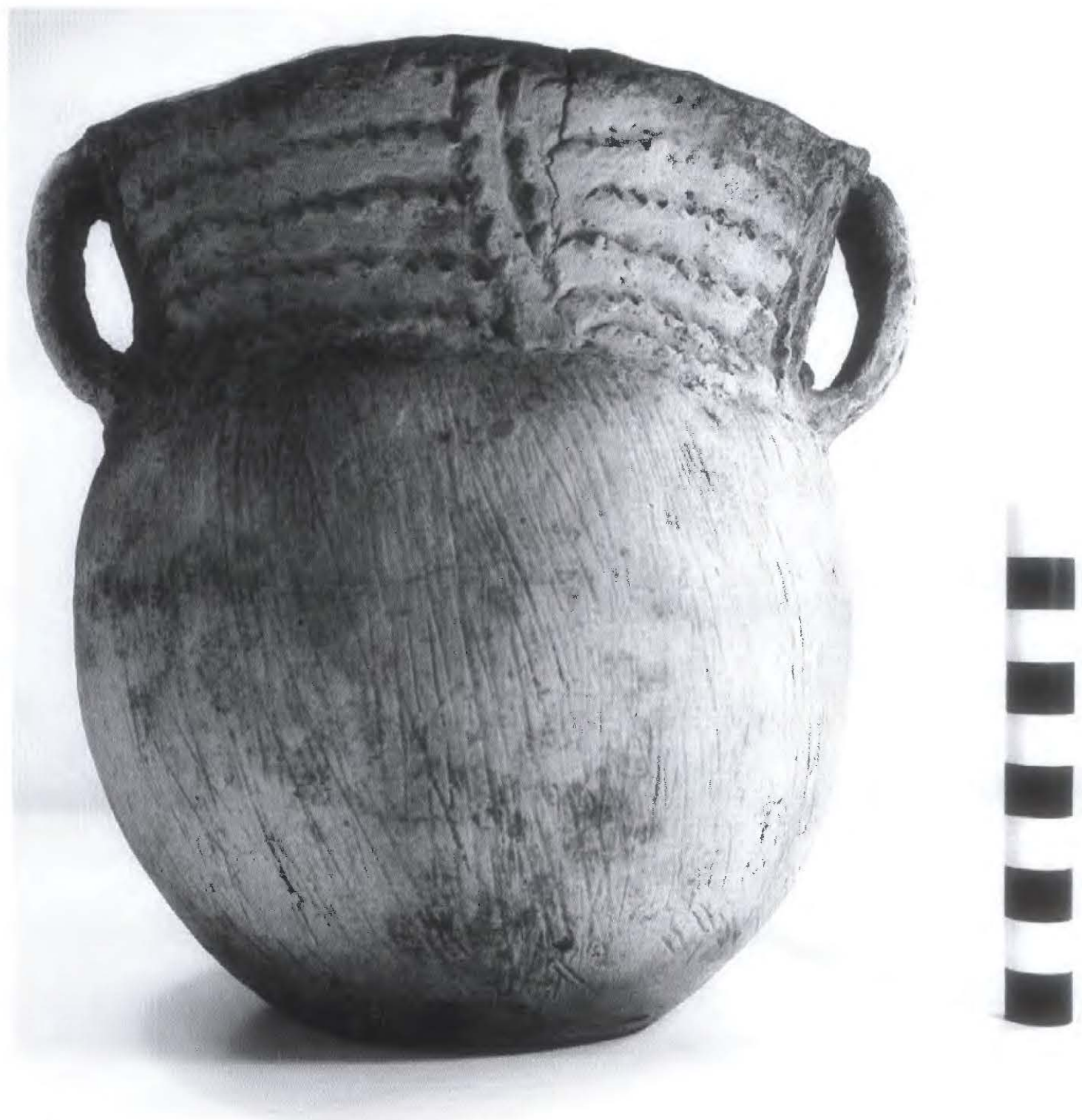

Figure 14. cf. Killough Pinched jar, Burial 3, Vessel 9.

BASE DIAMETER (IN CM) AND SHAPE OF BASE: 8.0; flat and circular

ESTIMATED VOLUME (IN LITERS): 2.3

DECORATION (INCLUDING MOTIF AND ELEMENTS WHEN APPARENT): The rim has five horizontal rows of pinching that are divided by either the two strap handles (both with vertical pinched rows) or two sets of three vertical pinched rows (Figure 14). The vessel body has diagonal to vertical brushing to within $1 \mathrm{~cm}$ of the vessel base.

PIGMENT USE AND LOCATION ON VESSEL: none

TYPE AND VARIETY [IF KNOWN]: cf. Killough Pinched 


\section{Burial 4}

No human remains were preserved in Burial 4; the size and depth of the grave pit suggests that this was the burial of an adult. The pit was $76 \mathrm{~cm}$ in depth, $74 \mathrm{~cm}$ in width, and approximately $150 \mathrm{~cm}$ in length (Figure 15). Three vessels were placed in the grave as funerary offerings, two-a Poynor Engraved bottle and a plain carinated bowl (see Figure 13a-b) near what would have been the right side of the head, and a large plain carinated bowl (see Figure 13e) by what would have been the lower left leg.

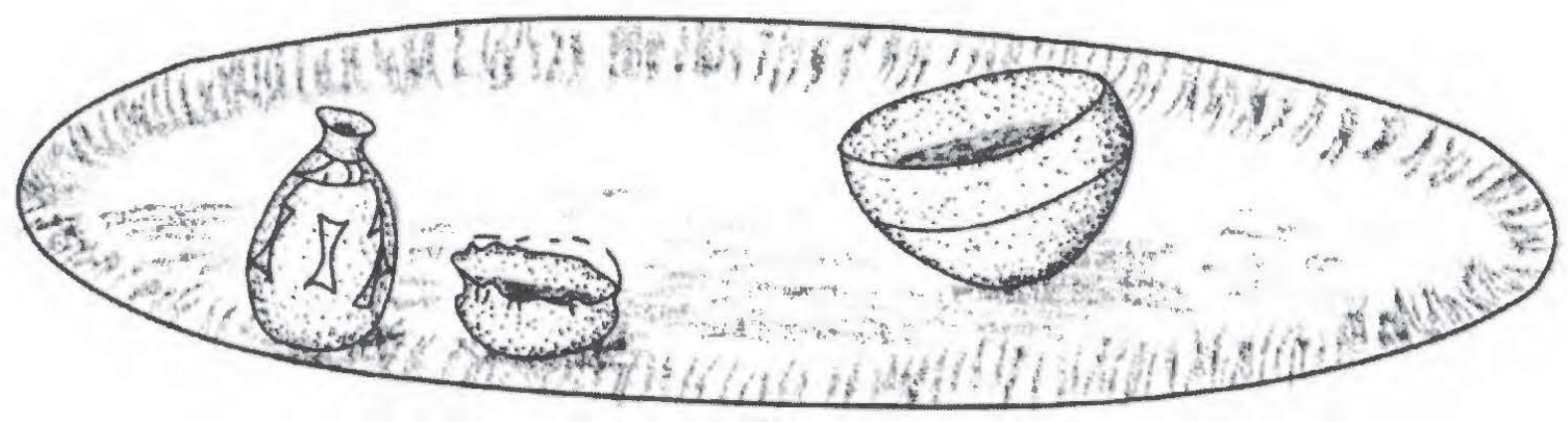

Figure 15. Burial 4 at the H. C. Slider site.

\section{Elbow Pipe Sherd}

An elbow pipe bowl rim sherd from the H. C. Slider site is in the Gregg County Historical Museum collections, but its provenience within the site is not known. The elbow pipe stem, tempered with grog, has four horizontal engraved lines on the upper part of the stem, and sets of curvilinear engraved lines on the lower part of the stem, perhaps extending onto the lower part of the bowl (Figure 16). This particular pipe resembles an upper Neches Var. C. elbow pipe (Perttula 2011:Figure 6-23). These pipes are found in ca. A.D. 1400-1650 Frankston phase sites, in both domestic and mortuary contexts.

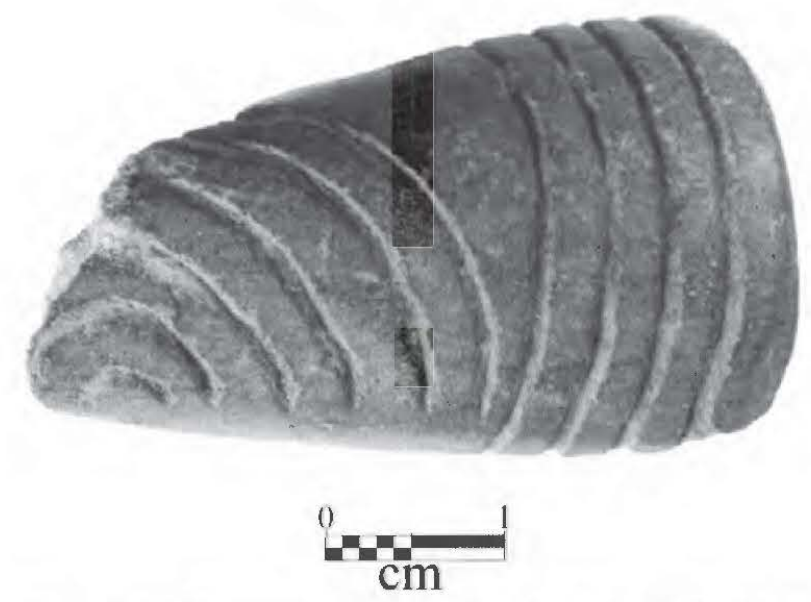

Figure 16. Engraved elbow pipe sherd from the H. C. Slider site.

\section{SUMMARY AND CONCLUSIONS}

The H. C. Slider site is a Late Caddo Frankston phase domestic settlement with a small cemetery on an alluvial terrace of the Neches River in western Cherokee County, Texas. Buddy Jones investigated the site in November and December 1967, documented three distinct midden deposits on terrace knolls (see Figure 
2), and knoll A had a small cemetery with four burials. Jones excavated the four burials, all of which were aligned with the body's head at the southeast end of the grave, the body in an extended, supine position, facing to the northwest. This is a common form of burial treatment in the upper Neches River basin at this time.

The burials each had associated funerary offerings, namely between 1-6 ceramic vessels. A total of 13 vessels were included with the burials, both fine wares $(n=4)$, utility wares $(n=5)$, and plain wares $(n=4)$. Among the fine wares are a Hood Engraved, var. Hood effigy bowl, one Poynor Engraved, Var. A carinated bowl, and two cylindrical Poynor Engraved bottles with short necks, while the utility wares include three Killough Pinched jars (one with a pedestal base), a diagonal incised jar (possibly Maydelle Incised), and a Bullard Brushed jar. The plain wares are globular-shaped $(n=2)$ and simple $(n=2)$ carinated bowls of several sizes.

The decorated vessels, and the distinctive vessel forms, from the burials are stylistically consistent with a Frankston phase component in the upper Neches River valley. The occurrence of the one Var. A Poynor Engraved vessel and the Hood Engraved, var. Hood effigy vessel at the site suggests that the burials date from the early part of the Frankston phase, from ca. A.D. 1400-1480 (see Perttula 2011:Table 6-37).

\section{ACKNOWLEDGMENTS}

We thank Patti Haskins for her help with our documentation efforts at the Gregg County Historical Museum. Lance Trask prepared the maps, burial figures, and vessel drawings based on the originals prepared by Buddy Jones.

\section{REFERENCES CITED}

Gonzalez, B.

2005 Caddo Tribal Religious Burial Ceremonies beyond Archeology. In A Rediscovering of Caddo Heritage: The W. T. Scott Collection at the American Museum of Natural History and Other Caddo Collections from Arkansas and Louisiana, by B. Gonzalez, R. Cast, T. K. Perttula, and B. Nelson, pp. 55-59. Historic Preservation Program, Caddo Nation of Oklahoma, Binger, Oklahoma.

Perttula, T. K.

2011 The Ceramic Artifacts from the Lang Pasture Site (41AN38) and the Place of the Site within an Upper Neches River Basin Caddo Ceramic Tradition. In Archeological Investigations at the Lang Pasture Site (41AN38) in the Upper Neches River Basin of East Texas, assembled and edited by T. K. Perttula, D. B. Kelley, and R. A. Ricklis, pp. 145-320. Archeological Studies Program Report No. 129, Texas Department of Transportation, Environmental Affairs Division, Austin. 